\title{
Graptemys gibbonsi Lovich and McCoy 1992 - Pascagoula Map Turtle, Pearl River Map Turtle, Gibbons’ Map Turtle
}

\author{
Jeffrey E. Lovich ${ }^{1}$, Will Selman ${ }^{2}$, and C.J. McCoy ${ }^{3}$ \\ ${ }^{1}$ U.S. Geological Survey, Southwest Biological Science Center, \\ 2255 North Gemini Drive, MS-9394,_Flagstaff, Arizona 86001 USA [jeffrey_lovich@usgs.gov]; \\ ${ }^{2}$ The University of Southern Mississippi, Hattiesburg, Mississippi 39402 USA [will.selman@usm.edu]; \\ ${ }^{3}$ Deceased
}

\begin{abstract}
Summary. - The Pascagoula map turtle, Graptemys gibbonsi (Family Emydidae), is a large aquatic species endemic to the Pascagoula and Pearl River drainages of Mississippi and southeastern Louisiana. It was previously considered part of the composite species G. pulchra. Sexual dimorphism is pronounced, with adult females (carapace length to $295 \mathrm{~mm}$ ) attaining more than twice the size of adult males (to $141 \mathrm{~mm}$ ). Although the species is locally abundant, populations are threatened by habitat destruction, commercial collecting, and target practice by unethical people who shoot basking turtles. The current IUCN Red List status is Lower Risk/Near Threatened, but the status should be re-examined due to recent surveys indicating population declines or the disappearance of the species from previously documented localities. In addition, genetic and pattern differences between populations in the Pearl and Pascagoula rivers suggest that the two entities should be managed separately to protect significant biodiversity.

Distribution. - USA. Restricted to the Pascagoula and Pearl River systems of Mississippi and Louisiana, as well as the lower Escatawpa River of southeastern Mississippi.

Synonymy. - Graptemys gibbonsi Lovich and McCoy 1992, Graptemys pulchra gibbonsi.

SubSPECIES. - None recognized.

STATUS. - IUCN 2008 Red List Status: Lower Risk / Near Threatened (LR/NT) (assessed 1996, needs updating); CITES: Appendix III (all Graptemys spp.; USA); US ESA: Not Listed.
\end{abstract}

Taxonomy. - The Pascagoula map turtle, Graptemys gibbonsi, was described by Lovich and McCoy (1992), who demonstrated that the species Graptemys pulchra Baur 1893 was a composite of three distinct, allopatric species. The other species in the complex include the Alabama map turtle (G. pulchra, sensu stricto) in rivers and tributaries of the Mobile Bay drainage, and the Escambia map turtle (G. ernsti) of the Escambia Bay drainage of southeastern Alabama and western Florida. The three species are welldifferentiated on the basis of morphology and pattern, and

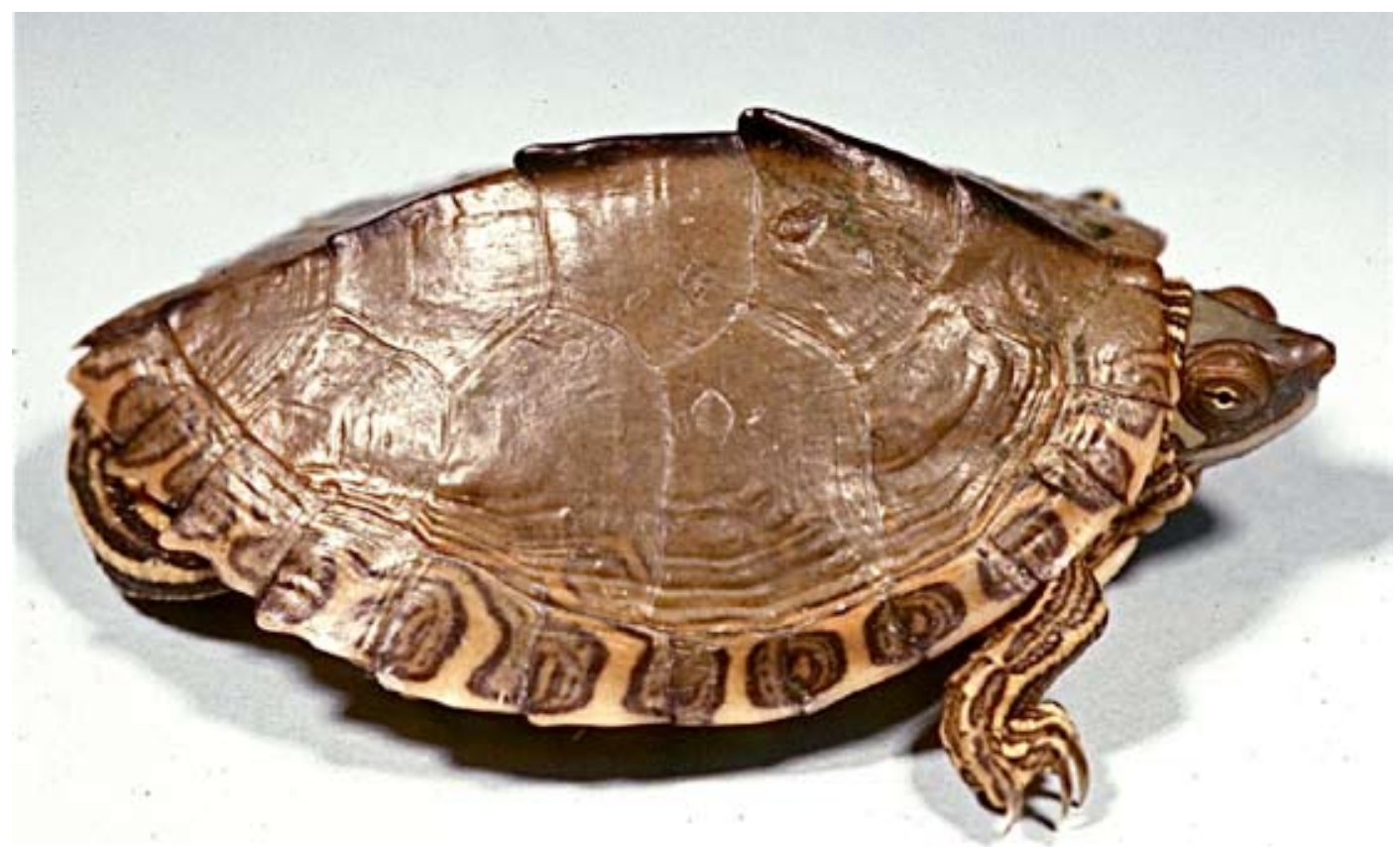

Figure 1. Adult male Graptemys gibbonsi from the Chickasawhay River, near Leakesville, Mississippi, USA. Photo by Jeffrey Lovich. 

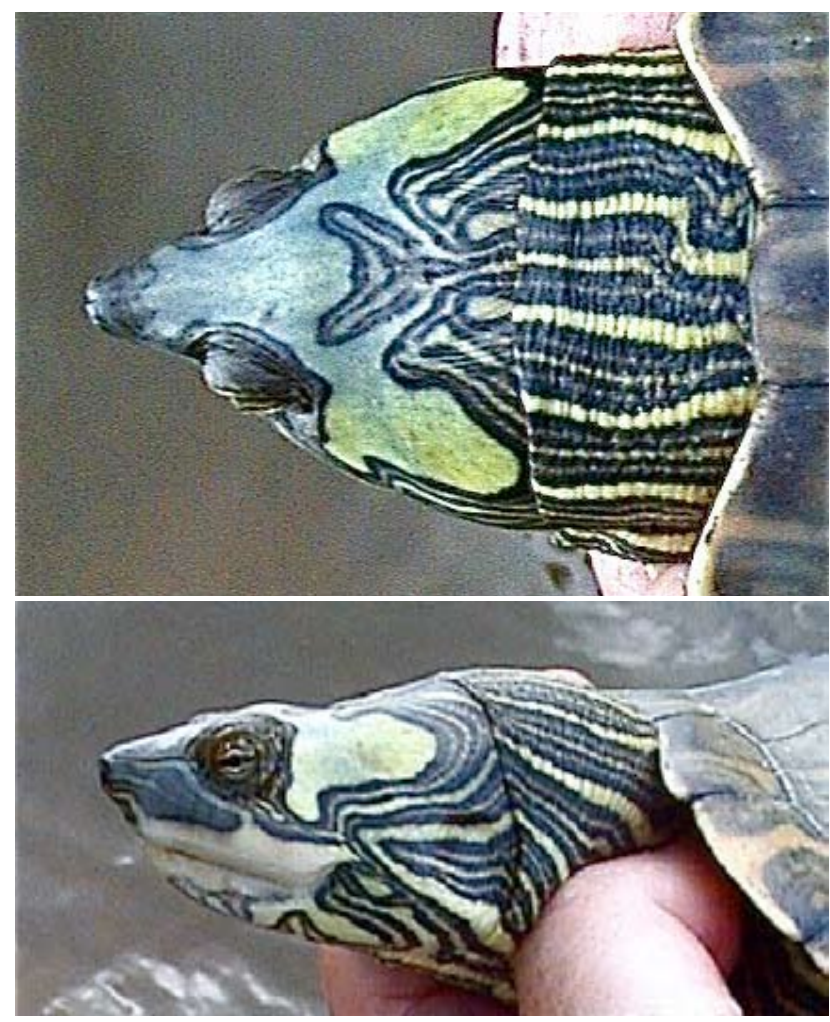

Figure 2. Head pattern of a female Graptemys gibbonsi from the Leaf River, Mississippi, USA. Photos by Will Selman.

exhibit divergent mtDNA genotypes (Lovich and McCoy 1992; Lamb et al. 1994). These three species, together with G. barbouri, form the Graptemys pulchra species group of the genus (Lovich and McCoy 1992) and all are characterized by extreme sexual size dimorphism and megacephalic adult females (Lindeman 2000). Additional information on G. gibbonsi (as G. pulchra, partim) was summarized by Lovich (1985).

Recently, Pearl and Pascagoula River populations of G. gibbonsi were shown to exhibit a high degree of genetic differentiation (Ennen et al. 2007a). The molecular divergence was greater than that exhibited between two other

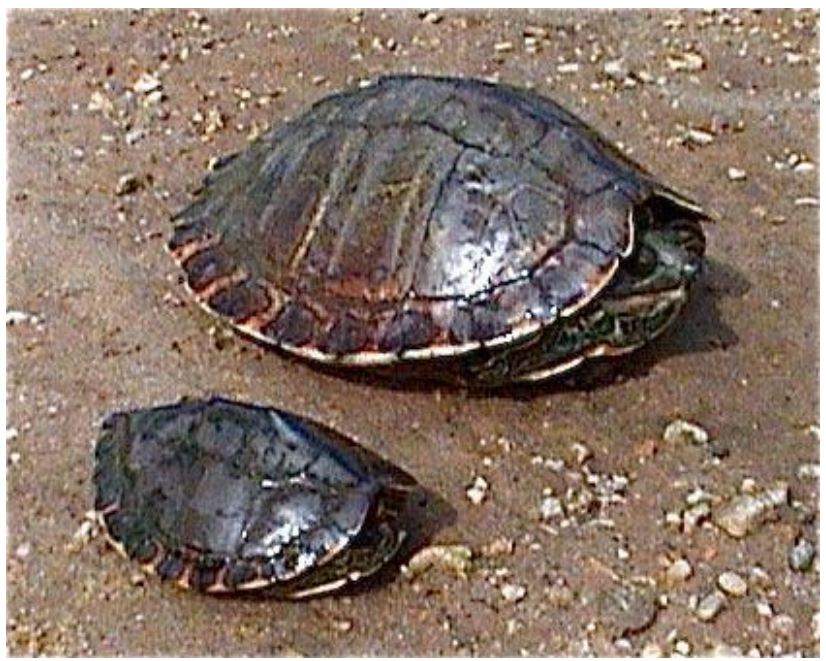

Figure 3. Graptemys gibbonsi exhibits dramatic sexual dimorphism between adult males (foreground) and females (background). Individuals from the Leaf River, Mississippi, USA. Photo by Will Selman.

Graptemys taxa from the same rivers with longstanding recognition as valid species. In this case, the yellow-blotched sawback (G. flavimaculata) from the Pascagoula River and the ringed sawback (G. oculifera) from the Pearl River are more similar to each other than the two populations of $G$. gibbonsi are to each other (Ennen et al. 2007a). The observed degree of differentiation requires recognition of populations in the Pearl and Pascagoula rivers as separate evolutionary entities to protect significant biodiversity. The authors are currently collaborating with others to further examine the level of differentiation exhibited between populations in the two rivers.

Description. - The Pascagoula map turtle is a large turtle that exhibits dramatic sexual dimorphism (females to $295 \mathrm{~mm}$ carapace length [CL], $3150 \mathrm{~g}$; males to $141 \mathrm{~mm}$ $\mathrm{CL}, 340 \mathrm{~g}$ ). The shell is high-domed, possesses a median keel, and has a single, wide, vertical, yellow bar on the dorsal surface of each marginal scute (Fig. 1). The median carapace keel is composed of salient spines on the posterior
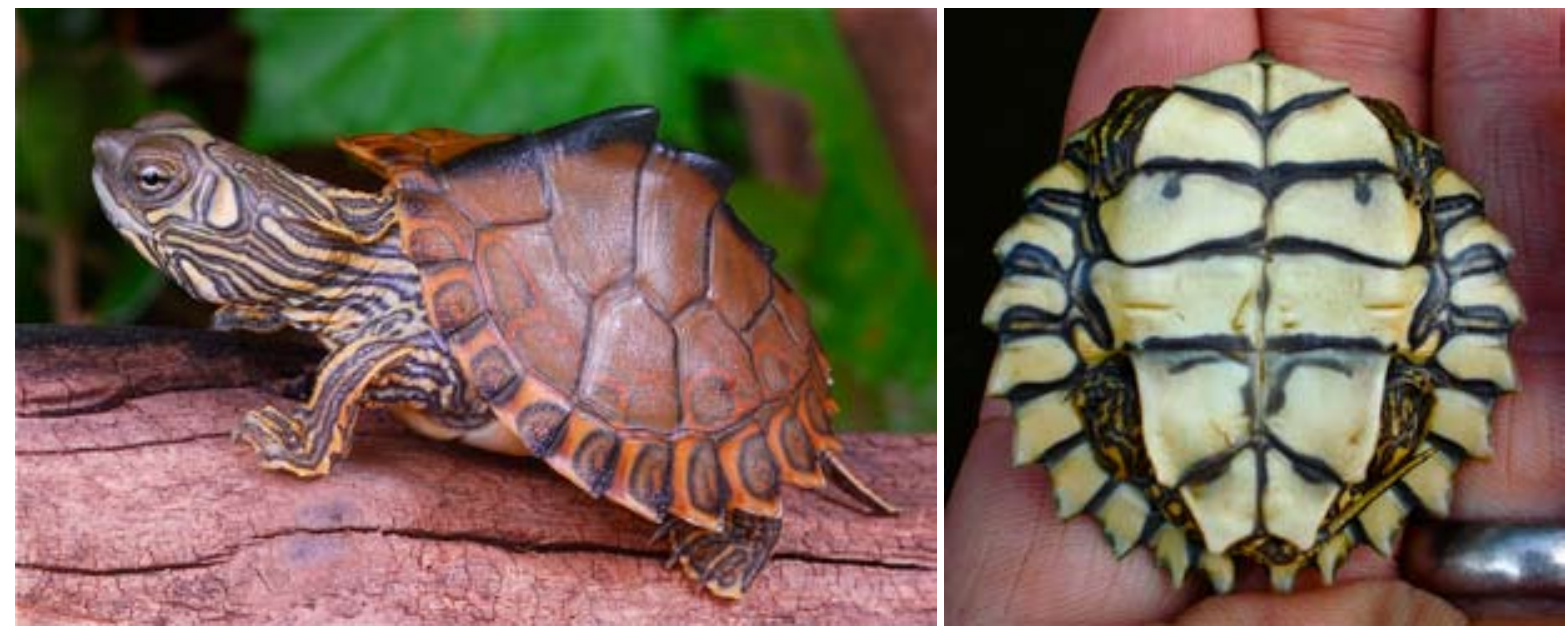

Figure 4. Hatchling Graptemys gibbonsi from Mississippi, USA. Left: from the Pearl River. Photo by Bill Love. Right: from the Leaf River. Photo by Will Selman. 


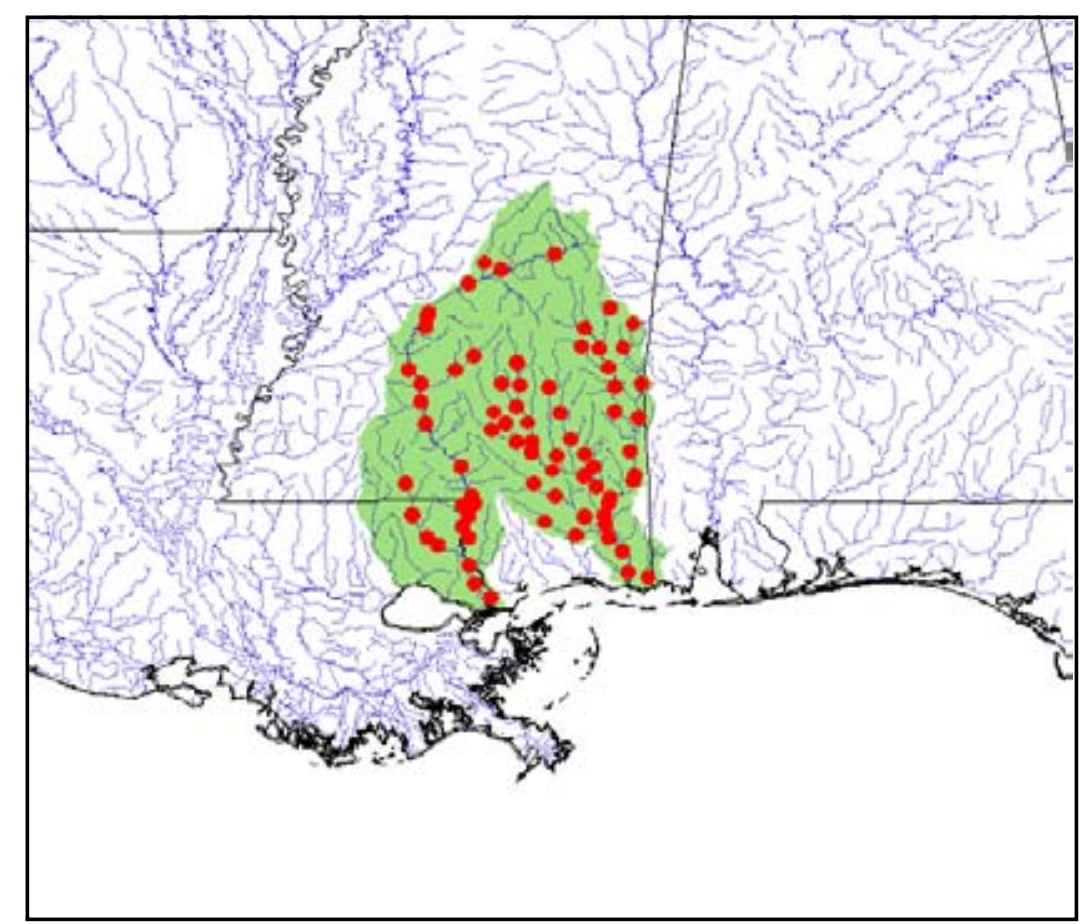

Figure 5. Distribution of Graptemys gibbonsi in the southeastern USA (Louisiana and Mississippi). Red points = museum and literature occurrence records based on Iverson (1992) plus more recent and authors' data; green shading = projected distribution based on GISdefined hydrologic unit compartments (HUCs) constructed around verified localities and then adding HUCs that connect known point localities in the same watershed or physiographic region, and similar habitats and elevations as verified HUCs (Buhlmann et al., in press), and adjusted based on authors' data.

portions of the second and third vertebrals, these features are more prominent in males and juveniles. A complete or broken black stripe, most pronounced anteriorly, marks the median keel of the vertebrals, and pleural scutes 1-3 have circular yellow markings on the distal parts. The plastron is pale yellow with dark pigment on some seams. Ground color of head and limbs is brown to olive with light yellow or yellowish-green stripes and blotches. The head pattern consists of a large interorbital blotch that is connected to the large postorbital blotches (Fig. 2). Supraoccipital spots are absent. The dorsal paramedian neck stripes are not expanded anteriorly, but may contact the postorbital blotches. A threepronged yellow blotch (nasal trident) is usually present on the dorsal head surface behind the nares and occurs more frequently in turtles from the Pearl River (Lovich and McCoy 1992).

In addition to being over twice the size of adult males, females (Fig. 3) have conspicuously enlarged heads with broad jaw surfaces. Males have longer tails with the vent posterior to the rim of the carapace, but do not have pronounced long foreclaws in comparison to other narrowheaded Graptemys species. Both sexes have relatively flat plastrons.

The color of G. gibbonsi hatchlings resembles the coloration of adults, but is much more vivid with greater contrast, particularly the net-like pattern on the pleural scutes (Fig. 4). Hatchlings are as wide as they are long ( $39 \mathrm{~mm} \mathrm{CL}, 40$ $\mathrm{mm}$ carapace width, $36 \mathrm{~mm}$ plastron length, 10 grams; W. Selman, unpubl. data) and have a serrate carapace edge at all marginal scutes, as well as a well-pronounced vertebral keel that is not as laterally compressed as adult males. The plastral markings of hatchlings often cover more area than the adult markings.

Allopatric species in the G. pulchra species group differ as follows: G. pulchra has the interorbital and postorbital blotches connected, concentric yellow circles on the dorsal sides of marginal scutes, and lacks supraoccipital spots and a nasal trident; in G. ernsti the interorbital and postorbital blotches are not connected, a nasal trident and supraoccipital spots are usually present; G. barbouri has a narrow interorbital blotch that ends in a point on the rostrum, a heart-shaped marking between the orbits, and a transverse bar on the lower jaw. Pascagoula River G. gibbonsi appear to have brighter coloration in comparison to those from the Pearl River. The former have wider yellow bars on the upper marginal scutes and narrower black bars on the lower marginal scutes, relative to those from the Pearl River (Lovich and McCoy 1992).

Distribution. - The Pascagoula map turtle is found in large rivers to small creeks within the Pascagoula and Pearl River systems of Mississippi and eastern Louisiana (Fig. 5). Previously published Pascagoula River system localities are in the Pascagoula, Leaf, and Chickasawhay rivers, Red, Bouie (aka Bowie), Okatoma creeks (Cliburn, 1971), Chunky River, and Tallahala Creek (Lindeman, 1998). Mount (1975) noted that G. pulchra $(=$ G. gibbonsi) did not occur in either Big Creek or the Escatawpa River, which are Alabama tributaries of the Pascagoula River. However, recent surveys by Selman and Qualls (2009) found G. gibbonsi present in the Lower Escatawpa in Mississippi, but no individuals in the Upper 
Escatawpa River of Mississippi that nears Alabama. The southernmost distribution within the Pascagoula River is near Vancleave, Mississippi, in the Lower Pascagoula River (Selman and Qualls 2009). These surveys also documented G. gibbonsi within a multitude of smaller creeks within the Pascagoula River system that were unsearched by previous surveys including: Bogue Homa, Bucatunna, Long, Gaines, Oakohay, Okatibbee, Souinlovey, and Tallahoma creeks.

Pearl River drainage populations occur in Ross Barnett Reservoir (Boyd and Vickers 1963; Lindeman 1998), the main stem Pearl River, Bogue Chitto River (Lovich and McCoy 1992), as well as the Yockanookany and Strong rivers (Lindeman 1998). Dundee and Rossman (1989) published a record of this species (as G. pulchra) from the Tickfaw River at U.S. Highway 190, Livingston Parish, Louisiana. Lovich and McCoy (1992) questioned that record, as the species is unknown in the Tangipahoa, Tchefuncte, and Amite rivers, which are located between the Tickfaw River and Bogue Chitto River (Cagle 1952; Cliburn 1971), the latter a known locality for the species. The southernmost distribution within the Pearl River is near the former town of Napolean, Mississippi, within the East Pearl River (W. Selman, pers. obs.).

Habitat and Ecology. - Graptemys gibbonsi is most abundant in large to medium sized rivers, where basking sites (logs and snags: Lindeman 1999), nesting sites (sandy beaches), and food species (especially clams and snails) are abundant. The species prefers clean water. Ernst and Lovich (2009) observed that G. gibbonsi was conspicuously absent below a paper mill outflow on the Leaf River in 1986, although the species was abundant in the river upstream from the pollution source. During recent surveys (2006 and 2008), this same locality had the highest abundance of $G$. gibbonsi within the Pascagoula River system (Selman and Qualls 2009), suggesting that pollution in that river stretch may have decreased in the intervening years. Saltwater is apparently avoided, and populations do not occur within a mile of estuaries (McCoy and Vogt, unpubl. data).

The introduced Asian mussel (Corbicula sp.) is an important food source for the species, especially for adult females which have broad crushing jaw surfaces (Ennen et al. 2007b; Lindeman and Sharkey 2001). Adult females also eat native clams, snails, and crustaceans. McCoy and Vogt (unpubl. data) found that G. gibbonsi (both sexes, all sizes combined) in the Chickasawhay River ate $82 \%$ (by volume) mollusks, and $5.7 \%$ each insects and vegetation. At a site on the Pearl River the diet was broader, with approximately $25 \%$ each insects and mollusks and $44 \%$ fish in stomach contents sampled. Males and small females (especially those less than $100 \mathrm{~mm} \mathrm{CL}$ ) are highly insectivorous.

Graptemys gibbonsi is primarily diurnal; basking, which is the most conspicuous surface activity, occurs at all times of the day. Basking times appear similar to the sympatric yellow-blotched sawback ( $G$. flavimaculata) with midday and late afternoon basking peaks (Selman, unpubl. data). Inter- and intraspecific basking competition has been also been observed with this species (Selman and Qualls 2008;
Selman, pers. obs.). Additionally, voluntary parasite release while basking has been observed on a female $G$. gibbonsi (Selman et al. 2008): observations noted that the carapace temperature of the basking turtle became hot enough to induce a leech to detach.

Gravid females were found from 3 May to August in 1978 and 1979 on the Pearl and Chickasawhay rivers (McCoy and Vogt, unpubl. data). Average clutch size was 7.5 in the Chickasawhay population, and 6.4 in the Pearl population. Individual females probably produce several clutches each year, based on the dates when gravid females were captured. Average egg measurements are $26 \times 38$ $\mathrm{mm}$, average egg mass is between 13.9 and $15.5 \mathrm{~g}$, and average relative clutch mass (clutch mass/body mass) is between 0.04 and 0.06 (McCoy and Vogt, unpubl. data). Nest sites are located on sandbars near the water's edge. Later studies from 2005-08 (Selman, unpubl. data) in the Leaf River population found gravid females from 3 April to 3 June. The mean size of gravid females was $22.4 \mathrm{~cm}$ (n $=8$ ) and the smallest gravid female was $17.9 \mathrm{~cm}$. Females presumably do not reach maturity for 15-20 years, while males probably reach maturity sooner. On 12 May 2007, a female $G$. gibbonsi (ca. $22 \mathrm{~cm} \mathrm{CL}$ ) was interrupted nesting at $0845 \mathrm{hrs}$ on a dirt road above a sandbar (Leaf River, Forrest Co., Mississippi; Selman and D. Strong, pers. obs.). The prospective nest location was $55 \mathrm{~m}$ from the nearest point of the river and 4.5-6.0 $\mathrm{m}$ above the water line. The nest location was mostly shaded under oak trees (Quercus nigra) and was silty to sandy with little vegetation within $0.5 \mathrm{~m}$ of the nest. Also, on multiple occasions, nesting females have been seen on sandy cut bank sections and thus, this species likely uses other nesting habitat than sandbars (Selman, pers. obs.).

Additional information on the ecology of G. gibbonsi is summarized by Ernst et al. (1994) and Ernst and Lovich (2009).

Population Status. - Historically, this species appeared to be abundant and easy to capture. Chaney and Smith (1950) caught 64 G. gibbonsi and G. oculifera (combined), in addition to 9 Trachemys scripta, 4 Pseudemys concinna, and 4 Sternotherus carinatus in 26 hrs of collecting along $9 \mathrm{~km}$ of the Pearl River. Cagle (1952) collected $98 \mathrm{G}$. gibbonsi (as G. pulchra) in the Pearl River, including 75 juveniles, 12 adult males, and 11 females (five of the latter were adults). Cagle (1953) also collected 105 G. gibbonsi in comparison to $51 \mathrm{G}$. oculifera in the Pearl River. Other early surveys by Tinkle (1958) found G. gibbonsi (as $G$. pulchra) to be the second most abundant turtle collected (15 individuals) within the Pascagoula River (behind $G$. flavimaculata, 21) and the most abundant turtle within the Pearl River (57 individuals to 30 G. oculifera), similar to what Cagle found.

Later surveys by McCoy and Vogt (unpubl. data) found that G. gibbonsi was the fourth most abundant turtle species at a Pearl River site, after (in order of decreasing abundance) $S$. carinatus, $T$. scripta, and $P$. concinna, but more abundant than G. oculifera, Apalone spinifera, A. 
mutica, Macrochelys temminckii, Sternotherus odoratus, and Chelydra serpentina. In the Chickasawhay River at Leakesville, Mississippi (type-locality for the species) G. gibbonsi was the most abundant aquatic turtle species, followed by A. mutica, S. carinatus, A. spinifera, G. flavimaculata, T. scripta, P. concinna, M. temminckii, and $S$. odoratus.

During the 1990s, Lindeman $(1998,1999)$ conducted spotting scope surveys throughout the Pearl and Pascagoula River systems. Graptemys gibbonsi were found to occur at much lower densities throughout the Pearl and Pascagoula River systems in comparison to G. oculifera and $G$. flavimaculata, both of which are federally listed species. Combined, G. oculifera and G. flavimaculata sometimes outnumbered $G$. gibbonsi dramatically, particularly within the Upper and Lower Pearl River (1 G. gibbonsi: 28.6 G. oculifera), West Pearl River(1:4.1), and Pascagoula River (1 G. gibbonsi: 7.2 G. flavimaculata). Of all the sites surveyed, $G$. gibbonsi never outnumbered $G$. oculifera within the Pearl River system and only outnumbered G. flavimaculata within the Chickasawhay River (1.5:1), Chunky River (no G. flavimaculata seen), and Black Creek (2:1), all of which are within the Pascagoula River system. Graptemys gibbonsi densities were also positively correlated with emergent deadwood abundance (Lindeman 1999). Lower G. gibbonsi levels in these drainages in comparison to prior surveys by Cagle and others were attributed to declining water quality and the negative impacts it has on mollusk populations, the primary food item of G. gibbonsi.

Two additional surveys for $G$. oculifera were conducted during the 1990s in Louisiana with pertinent information on G. gibbonsi populations. At seven sites within the West Pearl River Navigation Project, Dickerson and Reine (1996) documented much lower densities of G. gibbonsi in comparison to G. oculifera (16 G. gibbonsi: 534 G. oculifera). Two additional sites of the middle Pearl River of Mississippi were also surveyed by Dickerson and Reine (1996) and both were also found to have lower densities of G. gibbonsi in comparison to G. oculifera (125 G. gibbonsi: 2501 G. oculifera). Later, spotting scope surveys of the Bogue Chitto River (Shively 1999) noted fewer $G$. gibbonsi ( 370 or $22 \%$ of basking turtles) in comparison to G. oculifera (513 or 30\%). Graptemys gibbonsi occurred more frequently than G. oculifera in only 51 of the 133 river bends examined.

Later, bridge and boat/canoe surveys of the Pascagoula drainage (Selman and Qualls 2009) indicated that G. gibbonsi appeared to be locally abundant in the upper reaches of the Pascagoula River and sections of the Leaf and Chickasawhay rivers. Overall, G. gibbonsi was the third most abundant basking species within the Pascagoula River system and was the dominant basking Graptemys only in the Chickasawhay River (similar to McCoy and Vogt's findings), with $G$. flavimaculata being the most abundant basking Graptemys within the Pascagoula and Leaf rivers. However, the Chickasawhay River had fewer total basking turtles observed per bridge in comparison to the Pascagoula or Leaf rivers. Graptemys gibbonsi occurred within several of the smaller creeks/tributaries, but $P$. concinna was often the dominant basking species observed in these habitats.

No G. gibbonsi were spotted via bridge surveys in the previously documented localities of Okatoma or Bouie Creeks. A boat survey of the lower reaches of the Bouie River noted one individual, but this stretch of river has been severely impacted due to gravel mining (Selman and Qualls 2009). Also, extremely small populations of G. gibbonsi occur in the lower reaches of the Pascagoula and Escatawpa rivers and no individuals were spotted within Bluff Creek which has no previously documented records for G. gibbonsi.

The only population estimate for G. gibbonsi comes from the Leaf River site (Forrest Co., Mississippi) with an estimated 34.4 per river kilometer (rkm) $(95 \%$ confidence interval $=27.2-47.7$; Selman and Qualls 2009). For comparison, population estimates for the federally threatened species, G. flavimaculata, were made from 2005 to 2007 at the same locality and estimates ranged from 80.1 per rkm to 120.1 per rkm. Therefore, for these surveys G. gibbonsi was outnumbered by G. flavimaculata at the Leaf River site by $1: 2.3$ to $1: 3.5$. Similarly, Lindeman (1998) observed basking G. oculifera and $G$. flavimaculata densities on the Pearl and Pascagoula rivers to be up to 5.1 times higher than sympatric G. gibbonsi. Such was not always the case. Lindeman (1999) analyzed historical population trends that show G. gibbonsi was almost twice as abundant as G. oculifera on the Pearl River in the 1950s and 1960s, but less common than $G$. oculifera in the late 1970s. By the late 1980s and early 1990 s, the ratio of G. oculifera to G. gibbonsi ranged from 1.9:1 to 125:1. Similar declines were observed on the Pascagoula River from the 1950s to the 1990s relative to the abundance G. flavimaculata. Lindeman (1999) suggested that the reasons for changes in the abundance of G. gibbonsi relative to narrow-headed Graptemys congeners was related to the effect of water pollution on mollusk prey. Habitat degradation by channelization of rivers and industrial pollution, particularly from the paper industry, undoubtedly contributed to declines (Buhlmann and Gibbons 1997).

Trapping results at four sites (three within the Pascagoula and one in the Pearl) also indicate that G. gibbonsi population levels now are lower than G. flavimaculata or G. oculifera (Selman and Qualls 2009). Jones and Hartfield (1990) conducted similar trapping at five sites within the Pearl River system of Mississippi. Graptemys gibbonsi captures in 1990 were also lower at all five sites in the Pearl River in comparison to G. oculifera. The site shared by both studies had substantially higher levels of G. gibbonsi in 1990 (132 G. gibbonsi to 152 G. oculifera; $1: 1.15$ ) in comparison to 2005-06 (39 G. gibbonsi to 227 G. oculifera; 1:5.82). Additionally, there was no change in G. oculifera levels at this site during the same time period (Jones and Hartfield 1989, 1990; Selman and Qualls 2005, 2006). Thus, G. gibbonsi populations at this site have declined in the last 17 years, 
possibly due to impacts on mollusk prey items from the input of pulp-mill effluents from an upstream source at Monticello, Mississippi.

The Lower Escatawpa G. gibbonsi population appears to be the most vulnerable due to its disjunct location away from the main Pascagoula River population, as well as its extremely small size (Selman and Qualls 2009). Other populations that appear vulnerable to local extirpations are those that occur downstream of industrial/municipal effluents (i.e., Lower Pearl River) which likely negatively impact molluskan prey items. Lastly, Louisiana populations that occur within the Lower Pearl and Bogue Chitto rivers are further threatened due to the recent extensive collection of individuals for the pet trade (Selman and Qualls 2007).

Threats to Survival. - Few G. gibbonsi are found in streams supporting scant mollusk populations and none are found in streams in which mollusks are entirely absent. Thus, any form of stream pollution that has an impact on mollusk populations would also be potentially detrimental to populations of G. gibbonsi. Additionally, sedimentation of rivers and streams has been implicated in the decline of native freshwater mussels and gastropods in Mississippi (Jones et al. 2005), thus likely impacting the prey base of G. gibbonsi. Habitat modifications such as removal of logs or snags, channelization, or impoundment may eliminate habitat elements such as basking sites and nesting beaches that are essential for survival of this species (Lindeman 1999).

The species is exploited for the pet trade as far away as Hong Kong and other Chinese markets (Cheung and Dudgeon 2006). Individuals of all size classes are offered for sale at pet expos and online (C. Lechowicz, pers. comm.). Additionally, rumors within the pet trade that G. gibbonsi is a species of concern has surely fueled additional collection for this species. There is very little concrete information on the exploitation of G. gibbonsi, although it is reported that hundreds were collected in the Pearl River Basin in 2006 (Selman and Qualls 2007).

Nests of $G$. gibbonsi are presumably depredated by many species (including raccoons [Procyon lotor] and crows [Corvus spp.]) and hatchlings are depredated by largemouth bass (Micropterus salmoides; Carr and Messinger 2002) and other likely predators, including alligators (Alligator mississipiensis), weasels (Mustela spp.), herons (Ardea spp.), and egrets (Egretta spp.). On several occasions, dead females have also been found on sandbars, apparently depredated by mammalian predators while nesting (Selman, pers. obs.). However, humans are the only significant predators of adults. Local fishermen incorrectly regard turtles as vermin, or competitors for fish. Individuals are occasionally caught by fishermen (Ennen et al. 2007b) and several female G. gibbonsi remains have been found decapitated in fishing areas, evidently caught and killed by fishermen (Selman and Qualls 2007). Shooting basking turtles, a common practice by unethical people in some areas, may significantly reduce populations.
Conservation Measures Taken. - The state of Mississippi regards $G$. gibbonsi as a non-game species in need of management (T. Mann, pers. comm.). Commercial harvest is prohibited, and the possession limit is four turtles. Commercial collecting of native reptiles in Louisiana is regulated by the Louisiana Department of Wildlife and Fisheries (http://www.wlf.louisiana.gov/fishing/recreational/ regulations/reptilesandamphibians/). Graptemys gibbonsi is not state-listed as threatened or endangered in either Mississippi or Louisiana, but Mississippi is considering designation of $G$. gibbonsi as an endangered species due to recent findings (T. Mann, pers. comm.). In Louisiana, $G$. gibbonsi is listed as an Animal of Conservation Concern with a state element ranking of status level S3, defined as "rare and local throughout the state or found locally (even abundantly at some of its locations) in a restricted region of the state, or because of other factors making it vulnerable to extirpation (21 to 100 known extant populations)." However, some officials in Louisiana consider this species "common," even though all existing surveys within the state suggest that it is less common than G. oculifera, a federally threatened species. Protective measures implemented for federally threatened G. oculifera and G. flavimaculata should benefit $G$. gibbonsi due to the sympatry of the latter with the former.

Conservation Measures Proposed. - Conservation of G. gibbonsi should recognize the existence of two separate evolutionary entities at the very least (Pearl and Pascagoula River populations). Selman and Qualls (2007) suggested that Lower Pearl River populations have declined relative to $G$. oculifera in the last 17 years and Lindeman (1999) concluded that populations of $G$. gibbonsi declined relative to $G$. flavimaculata in the Pascagoula River, based on trapping data from the 1950s and 1960s. Furthermore, they suggested that G. gibbonsi should be considered for listing as threatened under the U.S. Endangered Species Act and Endangered by the IUCN unless their rarity in basking surveys could be demonstrated to be due to lower basking frequency relative to sympatric Graptemys, or larger populations were found upstream from their study sites, both of which are unlikely within the Pascagoula River system (Selman and Qualls 2009). The current IUCN Red List status for G. gibbonsi is Lower Risk/Near Threatened, but that status was assessed in 1996, and the species needs to be re-examined due to recent surveys indicating population declines and the disappearance of the species from previously documented localities.

Appropriate conservation measures for the Pascagoula map turtle include protecting and improving the water quality of rivers and streams occupied by this species, discouraging stream channelization and removal of snags, promoting streamside management zones and proper forest management practices within riparian zones, prohibiting or further regulating commercial collecting, and monitoring densities of existing populations.

All species of Graptemys are now listed under Appendix III (USA) of CITES (Convention on International Trade in Endangered Species). 
Captive Husbandry. - Most species of Graptemys can be kept successfully in captivity as long as their needs are met (Wahlquist 1970; Welch 1993). Captive specimens of molluscivorous and Graptemys can be successfully maintained on an artificial mollusk diet composed of a mixture of bone meal, oyster shell, trout chow, and agar (R.C. Vogt, pers. comm.). Captives are known to court and reproduce regularly (A. Redmond, pers. comm.), and may live in captivity for over 15 years (Snider and Bowler 1992).

Current Research. - Current research on the population status and distribution of G. gibbonsi, as well as basking behavior, is being finalized within the Pascagoula River system (Selman, unpubl. data). Additionally, genetic and morphological research is being conducted on the Pearl and Pascagoula River populations (Ennen, unpubl. data).

Future work on G. gibbonsi should include population surveys within the Pearl River system and a more intensive study on the reproductive biology and diet of this species. Additionally, marked populations (Selman, unpubl. data) at the Hattiesburg, Leakesville, and Columbia sites should be assessed occasionally to determine population densities, demography, growth, long-term movements, and longevity of G. gibbonsi.

Acknowledgments. - W. Selman would like to thank all those who assisted with field work on this species from 2006-08, especially field assistants Dustin Strong, Thomas Boczek, and Chris Griffith, who offered their canoeing and turtle observational skills. Jimmy Dale Odom, Presley's Outing, and Escatawpa Hollow Canoe and Camping (Larry Godfried) were extremely generous to allow us to use their private boat ramps to access remote portions of the Leaf and Escatawpa rivers.

\section{LITERATURE CITED}

BAUR, G. 1893. Two new species of North American Testudinata. American Naturalist 27(319):675-677.

BOYD,C.E. AND VICKERS,D.H.1963.Distribution of some Mississippi amphibians and reptiles. Herpetologica 19:202-205.

BuHLMANN, K.A. AND GiBBons, J.W. 1997. Imperiled aquatic reptiles of the southeastern United States: historical review and current conservation status. In:Benz,G.W.and Collins, D.E.(eds.),Aquatic Fauna in Peril: The Southeastern Perspective.Spec.Publ. Southeast Aquatic Res. Inst., Decatur, Georgia, pp. 201-231.

Buhlmann, K.A., Akre, T.S., Iverson, J.B., Karapatakis, D., MitTermeIER,R.A.,GEORGES,A.,RHOdin,A.G.J., vANDIJK,P.P., AND GiBBons, J.W.In press.Aglobal analysis of tortoise and freshwater turtle distributions withidentification of priority conservation areas. Chelonian Conservation and Biology 8(2):in press.

CAGLE, F.R. 1952. The status of the turtles Graptemys pulchra Baur and Graptemys barbouri Carr and Marchand, with notes on their natural history. Copeia 1952:223-234.

Cagle,F.R. 1953.The status of the turtle Graptemys oculifera (Baur). Zoologica 38:137-144.

CARR,J.L. AND MEsSInGER,M.A.2002.Graptemys gibbonsi,Predation. Natural History Note. Herpetological Review 33:201-202.

Chaney,A. And Smith,C.L. 1950. Methods forcollecting map turtles. Copeia 1950:323-324.
Cheung, S.M. and Dudgeon, D. 2006. Quantifying the Asian turtle crisis: market surveys in southern China, 2000-2003. Aquatic Conservation: Marine and Freshwater Ecosystems 16:751-770.

Cliburn,J.W. 1971. The ranges of four species of Graptemys in Mississippi. Journal of Mississippi Academy of Sciences 16:16-19.

Dickerson, D.D. AND ReINE, K.J. 1996. Habitat assessment and relative abundance estimates for the ringed sawback turtle(Graptemys oculifera) in dredging sites of the West Pearl River Navigation Project (Louisiana). Final Report prepared for the US Army Engineer District, Vicksburg, MS, $52 \mathrm{pp}$.

Dundee, H.A. and Rossman, D.A. 1989. The Amphibians and Reptiles of Louisiana. Louisiana State University Press, Baton Rouge, LA, $300 \mathrm{pp}$.

Ennen, J.R., Kreiser, B., Qualls, C., And Selman, W. 2007a. Molecular comparison of Graptemys gibbonsi from the Pearl and Pascagoula rivers. Final Report to the Linnaeus Fund of Chelonian Research Foundation, $21 \mathrm{pp}$.

Ennen, J.R., Selman, W., and Kreiser, B.R. 2007b. Graptemys gibbonsi (Pascagoula Map Turtle). Diet. Herpetological Review 38:200.

ERnst, C.H. AND Lovich, J.E. 2009. Turtles of the United States and Canada. Johns Hopkins University Press, Baltimore, MD, 827 pp.

ERnst, C.H., Lovich, J.E., AND Barbour, R.W. 1994. Turtles of the United States and Canada. Smithsonian Institution Press, Washington, D.C., $578 \mathrm{pp}$.

IVERSON,J.B. 1992.ARevised Checklist withDistribution Maps of the Turtles of the World. Richmond, IN: Privately printed, 363 pp.

JONES,R.L.ANDHARTFIELD,P.D. 1989.Density and population structure of the ringed sawback turtle, Graptemys oculifera (Baur): Year one. Unpublished report to Mississippi Department of Wildlife, Fisheries, and Parks. Jackson, MS, 34 pp.

JONES,R.L.ANDHARTFIELD,P.D. 1990.Density and population structure of the ringed sawback turtle, Graptemys oculifera (Baur): Year two. Unpublished report to Mississippi Department of Wildlife, Fisheries, and Parks. Jackson, MS, 47 pp.

Jones, R.L., Slack, W.T., and HaRTfield, P.D. 2005. The freshwater mussels (Mollusca: Bivalvia: Unionidae) of Mississippi. Southeastern Naturalist 4:77-92.

Lamb, T., Lydeard, C., Walker, R.B., and Gibbons, J.W. 1994. Molecular systematics of map turtles (Graptemys): a comparison of mitochondrial DNA restriction site versus sequence data. Systematic Biology 43:543-559.

LinDEMAN, P.V. 1998. Of deadwood and map turtles (Graptemys): an analysis of species status for five species in three river drainages using replicated spotting scope counts of basking turtles. Chelonian Conservation and Biology 3:137-141.

Lindeman, P.V. 1999. Surveys of basking map turtles Graptemys spp. in three river drainages and the importance of deadwood abundance. Biological Conservation 88:33-42.

Lindeman, P.V. 2000. Evolution of the relative width of the head and alveolar surfaces in map turtles (Testudines: Emydidae: Graptemys). Biological Journal of the Linnean Society 69:549-576.

Lindeman, P.V. and Sharkey, M.J. 2001. Comparative analyses of functional relationships in the evolution of trophic morphology in the map turtles (Emydidae: Graptemys). Herpetologica 57:313-318.

Lovich, J.E. 1985. Graptemys pulchra. Catalog of American Amphibians and Reptiles 360:1-2.

Lovich,J.E. AND McCoy,C.J.1992.Review of the Graptemys pulchra group (Reptilia: Testudines: Emydidae), with descriptions of two new species. Annals of Carnegie Museum 61:293-315.

Mount, R.H. 1975. The Reptiles and Amphibians of Alabama. 
Auburn University Agricultural Experiment Station, Auburn, Alabama, $347 \mathrm{pp}$.

Selman, W. ANd Qualls, C. 2005. Steroid hormone levels and reproduction in the yellow-blotched sawback turtle (Graptemys flavimaculata) and the congeneric ringed sawback turtle (Graptemys oculifera). Report to the Mississippi Department of Wildlife, Fisheries, and Parks. Jackson, MS, 33 pp.

Selman, W. AND Qualls, C. 2006. Steroid hormone levels and current population status of the yellow-blotched sawback turtle (Graptemys flavimaculata). Technical report to the Mississippi Department of Wildlife, Fisheries, and Parks and the U.S. Fish and Wildlife Service. Jackson, MS, 58 pp.

SELman,W. ANdQuALls, C. 2007.Distribution, status, and conservation of the Pascagoula mapturtle(Graptemys gibbonsi). Technical report to the Mississippi Department of Wildlife, Fisheries, and Parks and the U.S. Fish and Wildlife Service. Jackson, MS, 37 pp.

Selman, W. And Qualls, C. 2008. Graptemys gibbonsi (Pascagoula Map Turtle). Interspecific competition for basking sites. Herpetological Review 39:216.

Selman, W. AND Qualls. C. 2009. Distribution and abundance of two imperiled Graptemys species of the Pascagoula River system. Herpetological Conservation and Biology 4(2):171-184.

Selman, W., Strong, D., And Qualls, C. 2008. Graptemys gibbonsi (Pascagoula Map Turtle). Basking and parasite removal. Herpetological Review 39:216.

ShIvely, S.H. 1999. Survey for the ringed map turtle (Graptemys oculifera) in the Bogue Chitto River, Louisiana. Unpublished re- port to the Louisiana Natural Heritage Program and the Louisiana Department of Wildlife and Fisheries. Baton Rouge, LA, 50 pp.

SNIDER, A.T. AND Bowler, J.K. 1992. Longevity of reptiles and amphibians in North American collections, second edition. Society for the Study of Amphibians and Reptiles, Herpetological Circulars, No. 21, 40 pp.

TinkLE,D.W. 1958. The systematics and ecology of the Sternothaerus carinatus complex (Testudinata, Chelydridae). Tulane Studies in Zoology 6:3-56.

WAHLQUist, H. 1970. Sawbacks of the Gulf Coast. International Turtle and Tortoise Society Journal 4:10-13,28.

Welch, R.F. 1993. The all-American map turtles. Tropical Fish Hobbyist 41: 134-138, 141-142, 144.

Citation Format for this Account:

Lovich, J.E., Selman, W., AND McCoy, C.J. 2009. Graptemys gibbonsi Lovich and McCoy 1992 - Pascagoula map turtle, Pearl River map turtle, Gibbons' map turtle. In: Rhodin, A.G.J., Pritchard, P.C.H., van Dijk, P.P., Saumure, R.A., Buhlmann, K.A., Iverson, J.B., and Mittermeier, R.A. (Eds.). Conservation Biology of Freshwater Turtles and Tortoises: A Compilation Project of the IUCN/SSC Tortoise and Freshwater Turtle Specialist Group. Chelonian Research Monographs No. 5, pp. 029.1-029.8, doi:10.3854/crm.5.029.gibbonsi.v1.2009, http:// www.iucn-tftsg.org/cbftt/. 